\title{
Tax Planning of Small and Medium-Sized Real Estate Development Enterprise in the Establishment Stage
}

\author{
Zhang-Yin LU ${ }^{1, a}$, Zhi-Gao LIAO',b, \\ ${ }^{1}$ School of management, Guangxi University of science and technology, Liuzhou, Guangxi Zhuang \\ Autonomous Region \\ ${ }^{2}$ School of management, Guangxi University of science and technology, Liuzhou, Guangxi Zhuang \\ Autonomous Region \\ atheskyismy@163.com \\ ${ }^{*}$ Corresponding author
}

Keywords: Small and medium-sized real estate development enterprise, Tax planning.

\begin{abstract}
In recent years, real estate development enterprises become the focus of social attention. The country issued a series of related policies and measures to suppress prices rose too fast. Facing the national regulators strength increasing, and combined with the increasingly fierce competition in the market, real estate development enterprises' internal cost compression ability is more and more small. Tax as the external cost of enterprise, the amount will affect significantly the efficiency of real estate enterprise. The author used the mathematical analysis and case analysis, combined with the main characteristics of small and medium-sized real estate development enterprises in setting up stage, analyzed the tax planning of different organizational forms, got some tax planning methods in setting up stage. It has great significance to reduce tax cost of real estate enterprises, improve the efficiency of the enterprise.
\end{abstract}

\section{Introduction}

Tax planning in our country has experienced a process from scratch, but overall, the tax planning in our country is still in its infancy. Despite a lot about tax planning monographs in domestic, but it is still a new topic from the perspective of real estate enterprises. Along with our country establish tax agents, tax consultancy, real estate development enterprises will further contact with tax planning the reasonable and legitimate method of financial management.

Few works about tax planning when first introduced to China. Tang Teng-xiang published "The tax planning"(1993), which is the first tax planning monographs in China. They think tax planning refers to planning and arrangement beforehand to achieve the interests of the "tax" for operating, investment and financing activities.Zhang Zhong-xiu published "Enterprise tax planning strategies and cases"(1996).He has made a preliminary summary of the domestic tax method mainly according to the existing tax law in our country. The works about tax planning in our country increase gradually in the late 90s,such as Gai Di's points in the book of "Tax accounting and tax planning". He think tax planning is an arrangement aims to reduce tax burden, in order to achieve the company's financial goals without violating the premise of the relevant national laws and international recognized standards. However, tax planning research is focus on theory. Specializing in one industry or one kind of enterprise tax planning is seldom. Very few studies about how enterprises at all stages of tax planning. This paper mainly studies tax planning in setting up stage at small and medium-sized real estate development enterprises.

\section{Organization form and registration of tax planning}

\section{How to Choose Company, Sole Proprietorship Enterprise, Partnership firm}

The company belongs to the independent legal entity enterprise. The investors bear limited liability with its paid in the amount of capital contribution. The company's profits have to pay enterprise income 
tax, and then put the net profit distribution to the individual shareholders as dividend form, shareholders will pay individual income tax. That company wills double taxation.

The partnership is a form made up of two or more than two of the investor enterprise management together, each partner pay individual income tax in accordance with the division of the profits, A sole proprietorship enterprise is a enterprise established by individual independent investment, investors must pay individual income tax based on all revenue minus the cost. The partnership firm and sole proprietorship enterprise all belong to natural person enterprise. They don't have legal person qualification. Investors need to undertake unlimited liability, they don't need to pay enterprise income tax. But they need to pay individual income tax according to the individual businesses income from production and business operations.

If a taxpayer's taxable income is X. The partnership firm and sole proprietorship enterprise's personal income tax payable is $\mathrm{T}_{1}(\mathrm{X})$. The company's enterprise income tax payable is $\mathrm{T}_{2}(\mathrm{X})$. According to the above, we can use the following function show the tax payable of the taxpayers.

Option one: established the sole proprietorship enterprise.

$$
T_{1}(X)=\left\{\begin{array}{l}
X \times 5 \%, \quad X \leq 15000 \\
X \times 10 \%-750, \quad 15000<X \leq 30000 \\
X \times 20 \%-3750, \quad 30000<X \leq 60000 \\
X \times 30 \%-9750, \quad 60000<X \leq 100000 \\
X \times 35 \%-14750, \quad 100000<X
\end{array}\right.
$$

$\mathrm{R}_{1}=\mathrm{X}-\mathrm{T}_{1}(\mathrm{X})$

Option two: established companies

$$
\begin{aligned}
& \mathrm{T}_{2}(\mathrm{X})=\mathrm{X} \times 25 \%, \mathrm{~T}_{1}\left(\mathrm{X}^{\prime}\right)=(\mathrm{X}-25 \% \mathrm{X}) \times 20 \%=\mathrm{X} \times 15 \% \\
& \mathrm{R}_{2}=\mathrm{X}-\mathrm{T}_{2}(\mathrm{X})-\mathrm{T}_{1}\left(\mathrm{X}^{\prime}\right)=\mathrm{X} \times 60 \%
\end{aligned}
$$

Choose the option of pay less tax. Now if $T_{1}(X)<T_{2}(X)$, Choose option one(because $T_{1}(X)$ is already less than $\mathrm{T}_{2}(\mathrm{X})$, and option two should plus $\mathrm{T}_{1}\left(\mathrm{X}^{\prime}\right)$, it must be greater than option one), If $\mathrm{T}_{1}(\mathrm{X})>\mathrm{T}_{2}(\mathrm{X})$, than will continue to discuss. Let's make $T_{1}(X)=T_{2}(X)$, then,

$$
\left\{\begin{array}{l}
0.3 X-9750=0.25 X, \quad 60000<X \leq 100000 \\
0.35 X-14750=0.25 X, \quad X>100000
\end{array}, \text { calculate the } X=147500\right.
$$

When $100000<X \leq 147500, T_{1}(X)<T_{2}(X)$, choose option one.

When $X>147500, T_{1}(X)>T_{2}(X)$, continue to discuss.In fact,option two should plus the $T_{1}\left(X^{\prime}\right)$, in other word, totally $\mathrm{T}=0.4 \mathrm{X}$.

Option one $\mathrm{T}_{1}(\mathrm{X})=0.35 \mathrm{X}-14750$, Option two $\mathrm{T}_{2}=0.4 \mathrm{X}$

If $\mathrm{T}_{1}(\mathrm{X})<\mathrm{T}_{2}(\mathrm{X}), 0.35 \mathrm{X}-14750<0.4 \mathrm{X}$, conditions do not meet, therefore $\mathrm{T}_{1}(\mathrm{X})>\mathrm{T}_{2}(\mathrm{X})$, choose option two.

When $60000<\mathrm{X} \leq 100000, \begin{cases}T_{1} & (X)=0.3 X-9750 \\ T_{2} & (X)=0.25 X\end{cases}$

If $\mathrm{T}_{1}(\mathrm{X})>\mathrm{T}_{2}(\mathrm{X}), 0.3 \mathrm{X}-9750>0.25 \mathrm{X}, \mathrm{X}>195000$, conditions do not meet, therefore $\mathrm{T}_{1}(\mathrm{X})<\mathrm{T}_{2}(\mathrm{X})$, choose option one.

When $30000<\mathrm{X} \leq 60000, \begin{cases}T_{1} & (X)=0.2 X-3750 \\ T_{2} & (X)=0.25 X\end{cases}$

If $\mathrm{T}_{1}(\mathrm{X})>\mathrm{T}_{2}(\mathrm{X}), 0.2 \mathrm{X}-3750>0.25 \mathrm{X}$, conditions do not meet, therefore $\mathrm{T}_{1}(\mathrm{X})<\mathrm{T}_{2}(\mathrm{X})$, choose option one.

When $15000<\mathrm{X} \leq 30000,\left\{\begin{array}{l}T_{1}(X)=0.1 X-750 \\ T_{2}(X)=0.25 X\end{array}\right.$, therefore $\mathrm{T}_{1}(\mathrm{X})<\mathrm{T}_{2}(\mathrm{X})$, choose option one.

When $\mathrm{X} \leq 15000, \mathrm{~T}_{1}(\mathrm{X})=0.05 \mathrm{X}<\mathrm{T}_{2}(\mathrm{X})=0.25 \mathrm{X}$, choose option one. 
Table1: Selection scheme in different taxable income

\begin{tabular}{|c|c|}
\hline $\mathrm{X}$ & Option \\
\hline $\mathrm{X}>147500$ & Option two \\
\hline $100000<\mathrm{X} \leq 147500$ & Option one \\
\hline $60000<\mathrm{X} \leq 100000$ & Option one \\
\hline $30000<\mathrm{X} \leq 60000$ & Option one \\
\hline $15000<\mathrm{X} \leq 30000$ & Option one \\
\hline $\mathrm{X} \leq 15000$ & Option one \\
\hline
\end{tabular}

Through the analysis of the above three kinds of the nature of enterprise, we think that in the choice of this three types, large real estate development enterprise should choose the company enterprise because they need more capital and they have more difficulty in financing and management, so the risk is big. On the contrary, smaller enterprises should choose the partnership or a sole proprietorship enterprise.

Case 1: Someone running a company with a profit of 200000 yuan/year, what kind of form to set up the company can get the biggest tax profit?

Option one: Established sole proprietorship enterprise. Individual income tax $=200000 \times 35 \%$ $14750=55250$. After-tax profits $=200000-55250=144750$.

Option two: Established companie.Enterprise income tax $=200000 \times 25 \%=50000$. Individual income $\operatorname{tax}=(200000-50000) \times 20 \%=30000$.After-tax profits $=200000-50000-30000=120000$.

In conclusion, we should choose the option one. However, in the premise of not consider other factors.Compared to the company, partnership, sole proprietorship enterprise, the latter two is better than the former. Because they only need to pay individual income tax.But the company need to pay enterprise income tax and individual income tax. But if consider the enterprise's tax base, tax rates, national preferential policies and many kinds of factors comprehensive, companies also have positive aspects. Because only incorporated enterprise application national tax preferential policies.Secondly, we should not only look at local but also to see the whole in the calculation of the overall interests after-tax for different organization form. Because of the company enterprise's integrated measures is better than that of the general partnership and a sole proprietorship enterprise. Integration means that eliminate the overlap impact, then tax will reduce.

\section{How to Choose Limited Liability Company, Stock Limited Company}

It is more advantageous for real estate development enterprise's creation form to use stock limited company from the side of tax burden. Because our country related tax reduction policy, mainly applicable object is stock limited company. If the enterprise management in this form, they may get more preferential tax. For example, tax law in our country prescribe, invested enterprise need not serve as investors enterprise stock dividends income when put capital reserve(equity premium formed) into stock equity, The investor enterprise will not increase the tax base of long-term investment. In addition, from the financing perspective, stock limited company's financing mode is agile. But the establishment of a stock limited company 's condition is complex than limited liability company. Real estate development enterprise should consider comprehensive from all sides.

\section{How to choose to set up branches}

When the real estate enterprise development to a certain scale, in order to open up new market or facilitate customer service, the company inevitable to set up branches in other cities. But the new organization form for the establishment of a branch is different, will decide the company income tax pay way, and will further influence the company's overall tax. The form of branch including subsidiary company and branch company.

Subsidiary company refers to control a part of the amount shares by another company or it is actual control by another company in accordance with the agreement. It has an independent legal personality, it has its own property, It has its own property, articles of association and the board of directors, carry out business activities in its own name, engaged in all kinds of civil activities. It independently bears all consequences and responsibilities of corporate behavior.Branch company is incompetence for a legal entity. It governed by head office in the business, capital, personnel, etc. Branch companies have no 
independence in legal and economic, it just is an affiliate of the head office. It doesn't have its own property, articles of association and the board of directors.

From a tax perspective, whether it is a subsidiary or branch, both of them should pay income tax, but the tax treatment is different.

Table2: Tax treatment difference between subsidiary company and branch company

\begin{tabular}{|l|l|c|}
\hline $\begin{array}{c}\text { Sbsidiary } \\
\text { company }\end{array}$ & $\begin{array}{l}\text { Advantage } \\
\text { Belong to the legal person, can } \\
\text { enjoy preferential tax policies as a } \\
\text { legal person. }\end{array}$ & $\begin{array}{c}\text { 1. Subsidiary losses can't be reduced taxab } \\
\text { income of the parent company. } \\
\text { 2.Transactions between parents-subsidiary is } \\
\text { the company's trade, it should pay the } \\
\text { circulation taxes according to tax law. }\end{array}$ \\
\hline $\begin{array}{c}\text { Banch } \\
\text { company }\end{array}$ & $\begin{array}{l}\text { 1. Losses can be offset the head } \\
\text { office's income in the same year. } \\
\text { 2. Transactions between the head } \\
\text { office and the branch are insider } \\
\text { trading for the company. }\end{array}$ & $\begin{array}{c}\text { Incompetence for a legal entity. Some tax } \\
\text { incentives can't used alone. }\end{array}$ \\
\hline
\end{tabular}

From the table above, subsidiaries and branches have their own advantages and disadvantages in the tax treatment. Which branch that the company choose should be combined with the actual measurement comprehensive tax burden and make reasonable decisions.

Case 2: A city's real estate group companies named A have two branch company B and C. The group company earned pre-tax profit of 20 million in 2012, branch company B earned pre-tax profit of 2.5 million, branch company $\mathrm{C}$ loss of 1 million. The company's income tax rate is $25 \%$, the enterprise income tax $=(20000000+2500000-1000000) \times 25 \%=5125000$ yuan .

If $\mathrm{B}$ and $\mathrm{C}$ are subsidiary companies, total income tax was changed. A's enterprise income $\operatorname{tax}=20000000 \times 25 \%=5000000$ yuan.B's enterprise income tax $=2500000 \times 25 \%=625000$ yuan. C subsidiary losses and needn't pay enterprise income tax.

For the company as a whole, enterprise income tax is 5.625 million yuan, 500000 yuan more than option one.Due to the legally recognized parent-subsidiary company is not the same legal entity, so subsidiary losses cannot be charged to profit from the head office. But the branches and head office is the same legal entity, So losses in the business can be offset to reduce the group's overall tax burden. By the above cases, we can see that when the subordinate company losses, it is better that set the subordinate companies to branch company.

Through the above analysis, branches, we think, in the initial period, the possibility of loss is bigger, established a new branch of comparative advantage. Branch can be used to offset the losses of company profits, reduce taxable income. When they operate for a period of time to turn a profit, and tend to be stable, subsidiary will have more advantages, because you can enjoy preferential tax policies as a legal person. Taxpayers can separate out the branch at this moment and set up subsidiary.

\section{Tax planning in cooperative housing}

Cooperative housing is the form of cooperation development of real estate. It means one party provides land use right, the other party provide capital. Finally achieve the goal that both sides want houses.

Cooperative housing includes two forms. One kind way is exchange, it means that one party took out the money, the other party took out of the land. Finally achieve the goal that both sides want houses. Another way is to set up joint ventures, it means that the two sides become a shareholder to set up joint ventures, respectively in the form of land use rights and monetary capital to cooperative housing. Both parties take risk-sharing, profit sharing way of distribution after the completion of houses. The two different cooperation way produces different tax obligations, formed a huge tax planning space.

In the behavior of cooperative housing, we can full use of preferential tax policy of the country when carries on the tax planning. Tax law provisions: with intangible assets and real estate investment to 
become a shareholder, participate in accept the investor's profit distribution and share the risk of investment, the business tax shall be exempt.

Case 3:There are two real estate companies called A and B, cooperation to build company's house. A provides land use right. B provides capital. They agreed half-and-half points after the houses built. Assessed by the relevant departments after the project completion we know the value of the building is 12 million yuan. A and B each share houses value 6 million yuan.

Option one:Using the exchange method. A through the transfer of land-use rights and have part ownership of the new building, the business tax is levied on the transfer of intangible asset, the business tax payable $=6000000 \times 5 \%=300000 . \mathrm{B}$ transfer part of the ownership of the house price in return for part of the land use right, the business tax is levied on sells real estates, the business tax payable $=6000000 \times 5 \%=300000$.Both sides pay a total of 600000 .

Option two:Set up joint ventures. Both sides respectively in the form of land use rights and monetary capital to cooperative housing. Both parties take risk-sharing, profit sharing way of distribution after the completion of houses. Then the business tax shall be exempt. Joint venture's income of sales houses should paid the business tax, it is levied on sells real estates, the business tax payable $=6000000 \times 5 \%=300000$. Compared with option one less hand in 300000 .

Therefore, we think, the best combination of cooperative housing is one party provides land use right, the other party provide capital. Put the land use right and monetary investment to become a shareholder, set up joint ventures.

\section{Tax planning in separate departments}

Many internal departments in real estate development enterprise are an important part of company, and some departments' independence is very strong. Then we can divide out the department. From the perspective of tax planning, it may bring a lot of tax revenue. If the company divide out its own sales department, sales real estate to it first, then the independent department sales again. The land value-added tax can be exempted on the first step when selling real estate to the independent departments can be controlled within $20 \%$, and only levy land value-added tax on the second step.

Case 4: Real estate enterprise constructing ordinary standard residences for sale. The amount of deductible items is 11.6696 million yuan, standard housing's price is 15 million yuan.

The value-added ratio $=$ value added $\div$ the sum of deductible items $=(15000000-11669600) \div$ $11669600=28.54 \%>20 \%$.

Tax law provisions: taxpayers constructing ordinary standard residences for sale, where the appreciation amount does not exceed $20 \%$ of the sum of deductible items, the land value-added tax can be exempted. But taxpayers shall pay the land value-added tax all of its appreciation when exceed $20 \%$. In this case, the land value-added tax $=3330400 \times 30 \%=999100$ yuan. The business tax, city maintenance and construction tax and extra charges of education funds $=15000000 \times 5 \%$ $(1+7 \%+3 \%)=825000$. The revenue is 1506300 yuan if other costs are not considered the revenue $=$ $15000000-11669600-999100-825000=1506300)$.

If the company divide out its own sales department, sales real estate to independent department about 14000000 yuan. Then the independent department sales at price 15000000 . When the company sold with the price of 14 million to independent department, The value-added ratio $=(14000000-11669600)$ $\div 11669600=19.97 \%<20 \%$. The land value-added tax can be exempted. Then the independent department sold for the price of 15 million. The value-added ratio is less than $20 \%$. The land value-added tax also can be exempted. The real estate development enterprise's business tax, city maintenance and construction tax and extra charges of education funds $=14000000 \times 5 \%$ $(1+7 \%+3 \%)=770000$, The sales department 's total business tax, city maintenance and construction tax and extra charges of education funds $=(15000000-14000000) \times 5 \% \times(1+7 \%+3 \%)=55000$. Group earnings $=15000000-11669600-55000-770000=2505400$. More profit than before tax planning.

We believe that the key in separate departments' tax planning is sales section. The land value-added tax also can be exempted when the value-added ratio can be controlled within $20 \%$ in the process of selling real estate to the independent departments. Only outside sales levy land value-added tax.Using 
this method, of course, want to consider other aspects of the cost, such as the cost of set up a sales company. Reasonable use should in consideration of the specific conditions of the enterprise.

\section{Conclusion}

This paper mainly aims at the tax planning on real estate development enterprises on establishment stage. We research several aspects involved in real estate development enterprises on establishment stage. Analyze the tax planning from specific instances. The whole process has played a very good tax effect. We believe that the real estate enterprise's tax planning should be considerate various factors comprehensively. This can save the cost for the enterprise, make enterprise profit maximization.

In a word, real estate development enterprises have many ways to do tax planning. But it must be legal, operational and can bring benefit to enterprises. A practical scheme of planning must be associated with the enterprises' actual situation rather than form a complete planning scheme.

\section{References}

[1] Tang Teng-xiang, Tang xiang. "Tax Planning”. China financial \& economic publishing house, 1994. (In Chinese)

[2] Zhang Zhong-xiu. "Corporate tax savings on planning". Joint publishing house of China business, 2000. (In Chinese)

[3] Gai Di. "Tax accounting and tax planning". Dong bei university of finance and economics press ,2007.12. (In Chinese)

[4] Liu Rong. "Corporate strategy management and tax policy research". China economic publishing house, 2005. (In Chinese)

[5] Lu Peng, Feng Min-hong. "Tax planning of domestic enterprises organization form”, J. Taxation and Economy,2004(4), pp.70-72. (In Chinese)

[6] Wang Yan-li. "Tax planning of real estate development enterprise”,J. Friends of accounting, 2012(3), pp.70-71. (In Chinese)

[7] Li Xiu-en, Yu Jin-hua. "The land value-added tax in real estate development enterprise", J. Finance and Accounting, 2007.10, pp.46-48. (In Chinese)

[8] The ministry of finance and the state administration of taxation on the tax issue of equity transfer notice (finance and taxation [2002] num 191) (In Chinese)

[9] The ministry of finance and the state administration of taxation on some issues of land value-added tax notice (finance and taxation [2006] num 21) (In Chinese)

[10] The state administration of taxation on strengthening land value-added tax collection and administration work (national tax [2010] num 53) (In Chinese) 